\title{
Language At the Heart of the Matter: Symbolic Language and Ideology in The Heart of a Chief
}

"I just finished showing Dances With Wolves to my American literature class. I love that movie," Jessie announced as she walked into the faculty room.

Stan's ears perked up as he listened closely.

"Every time I show it," Jessie continued, "my students remark on the film's beauty. Some even talk about how the sound track echoes the film's emotions. I know it's long, but it seems to introduce our multicultural unit so well. It really generates genuine empathy for others."

"I know it is considered a classic." Stan interjects, "Nevertheless, I often use segments of Dances with Wolves to show how the film still advances stereotypes about the West and Native Americans."

"Oh, really?" Jessie asks. She pauses. "I always thought that it gives such a positive view of the Lakota people. Besides, Costner goes out of his way to include the native language and authentic clothing."

"Yes, he does," Stan continues "but imagine how you might feel about the portrayal of the Pawnee throughout the movie if you were a modern-day Pawnee." Jessie looks on thoughtfully. "The film still advances the stereotype of the good Indian against the bad Indian and places the white man in the position of savior."

"I agree," adds Debbie, another English teacher. "The genocide of

the Native American people takes a back seat to Dunbar's experience."

Mark, another history teacher, chimes in:

"Yes, it focuses so constantly on the white guy. When will Hollywood create a film where a Lakota, for example, is allowed to tell the tribe's story?"

"I guess I should have considered that," responds Jessie. "Especially when I try so hard to include literature in my classroom about marginalized groups written by members of those communities. I like movies so much I often forget to use that critical eye I so often use when analyzing literature and apply it to movies."

Many students in our

classrooms have not developed the critical skills to examine closely both the craft and the ideology of any work of art. As language arts teachers, part of our job is to help them examine art more completely, especially with literature.
"Yeah, me too," Stan agrees. "I used segments of the film in my history class for several years and watched it a couple of times myself before I realized that the film's message side-stepped some important ideological issues for Native American activists."

"I think you have helped me frame a follow-up discussion for tomorrow," concludes Jessie. "As a class we should consider how the power of art could help us see some issues as well as not see others."

This brief, and admittedly idealistic, faculty room conversation about Dances With Wolves demonstrates how a piece of art might be finely crafted and praised by many; yet, 
upon closer examination, the same piece of art can still present ideological problems. This is not only true of the films we choose to include in our classrooms; but it is equally true with the literature we select. Many students in our classrooms have not developed the critical skills to examine closely both the craft and the ideology of any work of art. As language arts teachers, part of our job is to help them examine art more completely, especially with literature.

It is important to remember that adolescents read the books that we, as teachers and critics of young adult literature, discuss and enjoy. Adolescents are the primary audience for this literature and hopefully, if a young adult book is successful, more young people than adults will read it. Recommending a book because it is beautifully written and well crafted is often not enough, especially if the book advances stereotypes and cultural misrepresentations. The opposite is also true; it is not enough for a book to be culturally accurate and receive praise if it lacks craft and artisanship. Those of us who both admire and analyze young adult literature, whether we consider ourselves teacher educators or literary critics, can provide teachers with the critical tools needed to engage students in discussions about books that include conversations of both craft and ideology. Keeping in mind this dual consideration, one side of this approach suggests that critics and teacher educators prepare novice teachers with the ability to recognize literary elements, metaphors, symbols, and figurative language. The other side of the approach

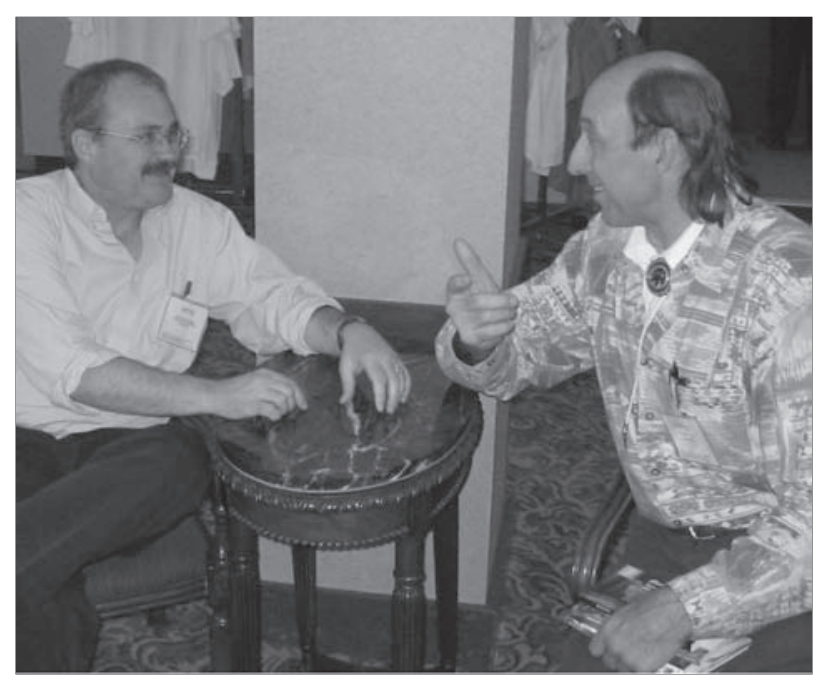

advocates considering how ideology is presented and asks teachers to read carefully and to contemplate the embedded messages of the texts that they will, in turn, share with their students.

New teachers should learn to carefully examine the literary techniques and the ideologies of the books they choose to teach and share with their students. Through a careful analysis of the books that are published and available for teachers and librarians to choose from, critics of adolescent literature, teacher educators, and teachers themselves should employ the tools of literary analysis to mediate the variety of ideologies that any given text either presents or neglects. Lyle (1997) reports that "ideology naturalizes, it historicizes, and it

The critique of a story is one measure of a book, the enjoyment and satisfaction that a story brings to young readers is quite another. To evaluate the skill and craft with which a story is rendered is a much different task than critiquing a novel's ideological stance. eternalizes" (1). If this is the case, then an examination of how carefully the ideology is embedded in the craft of the novel should aid in an overall evaluation of the text. Hollindale (1992) suggests "developments in literary theory have made us newly aware of the omnipresence of ideology in all literature" (23). We are all subject to the influence of ideology, which can briefly be defined as the positions, theories, and aims that form a sociopolitical view. The ability to evaluate the merit of any idea is a valuable skill to help students develop.

With practice, students can learn to identify and critique ideologies in the books they read. It is with this goal, that I embrace Hollindale's agenda, "Our priority in the world of children's books should not be to promote ideology but to understand it, and find ways of helping others understand it, including the children themselves" (27). We can't dismiss out of hand every book that does not align with our own ideological leanings nor can we avoid books of poor literary quality. Unfortunately, this often feels like the only course available, even though, in reality, many 
books of both commendable literary quality and a variety of ideological stances exist in schools and libraries.

The critique of a story is one measure of a book, the enjoyment and satisfaction that a story brings to young readers is quite another. To evaluate the skill and craft with which a story is rendered is a much different task than critiquing a novel's ideological stance. While the two approaches are different, both are important considerations when providing teachers with the tools they need to select novels for their students. I would argue that, as teacher educators in literacy programs, we could, indeed, do both. We would just find a larger range of conclusions about the novels we consider. Regardless of whether we are a critic who favors craft or one who privileges ideology, we place books along a continuum of approval. By considering both criteria carefully, the complexity of the continuum in which we evaluate the quality of a book expands. We might find that we admire both the craftsmanship and the ideology of a novel or we might admire one and trouble the other or, as often is the case, we can find both lacking and consider the novel weak and unsatisfactory. Of course, the ideal for a teacher or critic of adolescent literature would be to find examples of books that fit into the first category, where the novel rates high in both categories and use those books with the students we teach at any level.

The notion that we could quickly build such a list of books, with its accompanying ranking, and then use only those books, is a highly romantic notion and would ignore the numerous books that are already in libraries and classrooms. It is important to note that the process of selecting books is not as simple as it might sound. We may admire most of the literary qualities and disapprove of only a few in the course of the novel. On one hand, a novel may have an ending that is too quickly resolved, a character's symbolic use might be too transparent, or the use of authorial intrusion may feel overused. On the other hand, we might admire the ideological stance of a novel, but feel that its presentation is didactic, rather than subtly woven through the fabric of the narrative. It is in this spirit of a combined evaluation that I, through the lenses of critic, teacher educator, and classroom teacher, trouble my own satisfaction with The Heart of a Chief by analyzing the symbolic use of names and use of public discourse by Chris, the novel's main character (Bruchac, 1998).

\section{Explicating the Language of the Novel \\ In Joseph Bruchac's The Heart} of a Chief, symbolic language and its uses are central issues. Language exhibits its force throughout the novel in a variety of forms including: (1) the use of names with multiple symbolic meanings and (2) moments of public discourse that represent a powerful tool for understanding both within and between cultural groups in the novel. Bruchac's expert use of these literary tools draws the reader into the narrative of an engaging and compelling text. Because a Native American writes the novel, it avoids the issue of representation that often haunts even well crafted novels, but that are written by authors outside the ethnic community the novel attempts to portray (Yolen, 1992; Woodson, 2003). This paper presents evidence that The Heart of a Chief is tightly crafted, especially in terms of the symbolic use of language, it will also consider if the ending is equally satisfying with its quick and tidy resolution. Does the novel adequately consider a resolution that addresses the racial conflict that exists in the larger community of the story? Does it address the potential decay within the tribal community as represented by the advent of a casino on the edge of the reservation property? Can the Penacooks be led into the future by a chief with the inability to communicate effectively in the traditional language? 


\section{Examining the Names}

In The Heart of a Chief the symbolic possibilities of the main character's name are complex (Bruchac, 1998). When Chris Nicola explains his names, the reader is on a journey of discovery. In English, he is named for two saints, and in his native Penacook language his name means "bridge." He is named after a traveler and a giver of sacred gifts in English. In Penacook, the name is "only supposed to be spoken when you're on the water, or in sight of it" (3-4). However, the word "bridge" is a short translation for "Log Resting Firm on Both Shores and Wide Enough to Walk Upon" (4). Throughout the novel Chris bridges the gulf between two languages as he walks in and out of two linguistic worlds. His ability to use two languages helps him travel in distinct environments, leaving important "discourse gifts" at the doors of both the "white" world of Rangerville and the "Indian" world of the Penacook reservation. It is in the symbolic meanings of these names that the author's ideology manifests itself most clearly.

\section{St. Christopher, the demoted saint}

St. Christopher, the patron saint of travelers, has been "demoted" by the Catholic Church "because they think he never really lived" (Bruchac, 3). What does it mean to be given the name of a myth, of the person who never was? Chris' father, Mito, is separated and lost from the tribe. He continually looks for ways to return. Chris replaces the demoted patron Saint Christopher, suggesting that the one who guides the lost native traveler must come from within the tribe. While his English name suggests his significance to the traveler, it is in the connecting power of the native name, as a bridge, that provides the traveler a way back. Chris' actions are an attempt to communicate in and between both worlds of the novel. His success or failure at this task takes on significant ideological importance in the novel's ultimate message.

The name, Christopher, also carries religious significance other

than that of the lost saint mentioned by Chris' father. Christopher also has Christ at the root and means literally "bearing Christ" (Campbell, 1996-2002). ${ }^{1}$ While the traditional language and customs still carry power on the reservation, the native peoples attend the Christian church. Can this religion provide answers to the Penacook tribe if the symbol of movement, Saint Christopher, is stripped of its power? This is a group of people who face serious challenges as they travel into the future. The traditional uses of their land shrink and the influences of the outer world continue to encroach. The resources of this "new" religion have been found wanting. The author's ironic use of the name troubles the value of the white religion for these people and their future. By countering this white name with the native name the author points to the power of tradition and suggests a method of return. The literary trope of naming and the ideology work hand in hand.

\section{Pontiac's legacy}

Chris's identity as a traveler is supported by the symbolic use of another proper name. His grandfather's old Pontiac is now only a symbol of travel mounted on blocks. The car's model invites a comparison to Chief Pontiac, who led the Ottawa Indians in the 1750s and was the head of an intertribal group consisting of the Ottawa, Potawatomi, and Ojibwa people

“The old Pontiac doesn't have any tires and it sits up on blocks" (100-101). This tool, co-opted from the white man, is no longer meeting the needs of the tribe. Can any tool, then, taken from the white man successfully meet the needs of this tribe?
(Encarta ${ }^{\circledR}, 2003$ ). The car once served his grandfather as he traveled around the area maintaining his connection with other native tribes (Bruchac, 101). The efforts to preserve alliances between tribes, sustaining their culture in the face of the advancing white culture, become more difficult; "it has been ten years since there was a battery. But even if there was one, the old Pontiac doesn't have any tires and it sits up on blocks" (100-101). This tool, coopted from the white man, is no longer meeting the needs of the tribe. Can any tool, then, taken from the white man successfully meet the needs of this tribe? 
Chris sits in the car and imagines the journey that he must make. When his grandfather comes to talk with him in the car, Chris tells him, "Can't take my hands of the wheel when I'm driving” (Bruchac, 107). His grandfather understands the difficulty and responds, "not when we still got such a long way to go" (107). It is even a longer way to go when the symbolic vehicle of travel in this book is inoperable. Nevertheless, together Chris and his grandfather build a bridge between each other that covers the generational gap that Mito, Chris's father, has left in the family. Mito is the lost traveler in the story, the one who has wandered and looks to return. While Chris looks for ways to help the lost traveler return, Mito's own father, Dado, with his experience as a provider for the tribe and the family, supports Chris in his efforts. His attempts to help his father's return foreshadow his efforts to help the tribe. As Chris and his grandfather support each other to bridge the gap left in the family, they work together to close the gap that is left in the tribe. Again, the ideology of the text is intertwined in the craftsmanship of the novel.

\section{Deconstructing Columbus}

The name, Christopher, also carries the added burden of being the first name of Columbus. The irony that an Indian boy carries that name and also serves as the hero of a story about conflict among native peoples is hard to ignore. Many books, published just before the quincentenary of Columbus's arrival in this continent in 1492, ignore the destructive influence of Columbus's arrival. One children's book, Encounter, gives a very different representation of the event in both the text and the illustrations (Yolen and Shannon, 1992). The novel breaks new ground in its presentation of Christopher Columbus with its portrayal of the destruction of an entire tribe of people. Bruchac, a Native American of the Abenaki people, a novelist, and an educator, is certainly aware of the controversy surrounding Christopher Columbus. The name, Christopher, with its multiple meanings results in a problematic choice for the protagonist of The Heart of a Chief (Bruchac,
1998). Selecting Columbus' name, with the baggage it carries in the Native American community, troubles the action of the character that bears the name and the solutions that he participates in are ambiguous. Certainly, Bruchac wants the readers to consider the burden this name places on the character, just as a variety of influences from the white culture place burdens on native peoples as they try them on. Native peoples often negotiate new names, but also new clothes, new homes, new religions, and new ways of making a living. This use of a name that suggests so much ambiguity, troubles the tone of the novel. Can a character with this name reclaim its positive power and supply the community with appropriate and useful gifts? The symbolism of the name "Christian" and its close association with Columbus suggests an ideology that troubles the tidy conclusion of the novel. To present such a conflicting message and leave it untreated weakens the overall ideological stance of the novel.

\section{The Gifts of St. Nicholas}

Chris's family name, Nicola, is a shortened version of Nicholas, "back when the Europeans gave us names, we still said and spelled them our own way" (Bruchac, 3). St. Nicholas is most commonly known as Santa Claus, and as such, is the giver of gifts. In a pure sense, the person should be a giver of gifts that reminds Christians of the gift of Christ's life. He is also the patron saint of children. Its original etymology stems from the Greek name Nikolaos that means "victory of the people" from Greek nike "victory” and laos "people.” The name suggests a powerful victory for this young boy who travels back and forth between two worlds. As a giver of gifts, Chris seeks the gift that will be of value for his people. It is his ancestral duty and their gift to the tribe. In his letter Mito reminds the tribe, “[o]ur family has always defended the heart of our land. We will not stop doing that. . . . If we have to sacrifice a part of the land, it should not be the heart" (151-152). With this in mind, the family's next gift is a gift of land, land that is on the edge of the reservation 
instead of at its heart on the island (152). While the land will be lost to a casino, it is land that has known greater loss; an accidental fire has killed several members of the Nicola family (70-71). If the land can now save the heart of the land, perhaps the dead can now rest (152). The family seeks to provide for the tribe and bring closure to their own sense of loss.

\section{Being the Bridge}

Chris's Penacook name presents an important interpretive activity for the readers of the novel. For readers, it is the unknown name. While all the names given to Chris are connected with spirituality, this tribal name is the most powerful. The reader is never allowed to read the name only its translation, it is under erasure and we can only imagine its power (Derrida, 1978). It is not given a clear sign or logos, the reader must provide the foundation on which to build this "almost" bridge. Chris serves as the connector between several groups and individuals in the novel. For example, he and his grandfather physically connect to bridge the emotional gap that Mito's absence has left in the family.

He keeps his hands on my shoulder. It rested there lightly, but it is like a jumper cable attached to a dead battery. It is all that keeps me going right now, all that keeps me from giving up. He knows what
Bruchac uses other language patterns to support the ideology woven throughout the novel. He carefully develops his main character as a boy bound to language and intrigued by its power and potential. has just been taken away and he knows what he is giving me. I look over at Doda and I see the sadness in his eyes. He has had something taken away from him too. Part of my responsibility now, I see, is to give back to him (Bruchac, 107).

Together they build the bridge that covers the gap of Mito's absence. The power of Chris's native name trumps the English name's diminished power. The problematic meanings of his English names in the modern world are given direction by the power of his Pencacook name. At the end of the novel, Chris and Doda stand together in the tribal meeting and speak for Mito. By delivering his father's message, Chris begins to bridge the gap of leadership that Mito has left in the tribe and to serve as his surrogate. It is with this unspoken name that Bruchac has most powerfully blended the use of the literary trope of naming and ideology. Leaving the name unknown to the reader gives it added strength. The text continually suggests that the English names are inadequate. If they work at all, it is in conjunction with the Penacook name. It is difficult to misread the political stance of the author with this theme.

\section{Analyzing the Opportunities for Public Discourse}

Bruchac uses other language patterns to support the ideology woven throughout the novel. He carefully develops his main character as a boy bound to language and intrigued by its power and potential. Through a variety of opportunities for public discourse Chris' influence and growth is expressed in both his native community and in the white community.

\section{Defending the island}

Throughout the novel, Chris is trying to appropriate the power of using both the English and the Penacook languages, deciding which messages are clearest in each language and to which audience. Chris' action, after burning the surveyor's stakes, brings the conversation concerning the tribe's future into the open. In his excitement, he speaks in both Penacook and English. This symbolic combination of languages represents the tribe's two divisions and highlights the ideological tension of the novel. Tribal members who hold close to the old language represent those who resist the casino and the dangers that it may bring. The new language, English, is representative of the new chief "who has forgotten a lot of [their] language" and must have conversations translated for him (Bruchac, 150). Chris's speech is powerful and captures the attention of his young friends and the adults who arrive to investigate the fire.

"Their eyes are wide and they are staring at me. Gartersnake's mouth is open. I am talking in both Penacook and English now. . . The island has to stay the way it is because it is our heart. It beats like a drum. I say it in Penacook. I don't say much in 
Penacook, but every time I do, all of the adults look at me and then look at each other (45-46).”

Chris makes a stance as the defender of the island and for its position as the heart of the tribe's land. In reality, it is a much larger issue. What should the tribe do to flourish economically and still protect and nurture their lands and traditions?

While Chris may have the heart of a chief, he is still a novice in the tribe's political conversations. It is not until after church the following day that Chris begins to realize what he has started. He is invited home with Belly Button's family and shunned by others, "a couple of grown-ups patted me on my back, while others turned their backs on me" (50). His friend's father indicates that the arrival of a casino will divide the tribe (50). He "realizes for the first time how some people feel that a casino is against our traditional way of life” (50). Chris's position as a bridge within his family is clear. The question remains: Can he find the words to act as a bridge between the conflicts within the tribe?

Although his position in the tribe is still in limbo, he has spoken with power in both languages. This conflicting language use mirrors the conflicting ideological impulses of the novel. Can the Penacook tribe maintain its identity while allowing the encroachment of white society in the form of a casino? His influence is strong as Auntie reports in a phone conversation with Mito, “'[l]ike a sagamon,' she says. 'That's how he talked, they say. Everyone had to listen. It touched their hearts"” (63). He becomes the instrument that bridges two opposing forces in the debate. At this point in the narrative, the majority of the tribe's members favor the casino and the jobs it promises. His speeches have been impromptu and unpracticed to this point. He needs an apprentice, an opportunity to think about the power of speech and its presentation in public. The author makes it clear that communal discourse with the opportunity for give and take among its members is the appropriate method of decision making in the native community (95). It is this method of collaborative activity that Chris experiments with in the larger community outside of the reservation.

What's in a name? or What does it mean when you call me that?

The next example of language as public discourses begins to position Chris as voice for his people within the white world, which surrounds and encroaches on the reservation. Chris begins to master the language of the conqueror. He is unanimously selected as the leader of his class group. Using native people's traditions, his group decides to investigate the use of the Indian names for sports teams. Chris is nominated to be the leader of his group by Katie. Her father is Mohawk and her mother is white; in this position it is appropriate that she ushers Chris into this position of power. With a foot in each world, she also serves as a bridge that provides Chris with the opportunity to represent his people in the predominantly white world.

The native children are not immune to the racist impulses in English. When Chris finds out that Katie is an Indian, he begins to think about her in terms of a "Cherokee Princess" (23). Chris and his friends claim to know what kind of Indians they are,

The kind of Indian you don't see in Hollywood movies. No noble savages. No horses or headdresses. No tipis and no buffalo. No Tonto (which means "idiot" in Spanish) to the Lone Ranger. We are a different kind. The kind of Indian who gets ignored at best and treated like dirt at worst (2324).

This awareness does not, however, prevent them from referring to Katie as a "Cherokee Princess" and evoking the stereotypes that all female Indians must be princesses and all males must be chiefs (23). Chris has much to learn as he progresses. As he negotiates the stereotypes that the white world has placed on the Indians, he must and does acknowledge that he is caught up in the perpetuation of the same racism. This 
self-conscious examination by the character is what is missing from the ideology of the novel's tidy resolution. Bruchac creates a situation where the character's contemplation of the ramifications of the tribe's actions would be a logical extension of the narrative; unfortunately, it remains unconsidered and unexplored.

When Chris accepts the position as group leader, he suggests they use his tribal rules for discussion and decision-making. First, when some one is talking no one can interrupt and second, everyone has to agree with the final decision (95). They agree and not only work together on the project but also have a conversation about Native American perceptions of Thanksgiving. In this normal group setting, developed through the natural flow of the plot, Bruchac has provided an opportunity for his main character to calmly explain a Native American perception of the event. He has seamlessly included ideology in the novel using the literary techniques of plot and character development. This group of children work together gathering information, learning more about each other and become friends. It is in the comfort of this group that Chris realizes that he can speak the things he really feels, "I pause for breath. I've gotten into what can only be called a rant, but everyone at our table has been listening to me" (110). He gains power from this recognition that he is listened to and supported by Katie and his white classmates. It has been the proving ground for his voice that will represent the feeling of native peoples to a wider, more public audience.

By the following day, a significant number of adults representing the various communities are in the classroom. It is no longer a simple class report. It is an opportunity for the group to display their ideas with Chris as their concluding presenter. They make their points by including skits, jokes, and a serious presentation of ideas gathered from the research of all the members of the group. As is the case with Chris's speech at the island, we as readers are not given all the words, just the effects of their power. In both cases, they are masked, hidden from the reader. Like his unspoken name we are left to image them. The power is evident, a school board member suggests. "I would hate to be up against you in a debate. You have a career in politics" (130). Indeed he does, as we are reminded in his conversation with the principal. The principal asks if a chief some years earlier was his relative. Both Chris and the readers are reminded that this is a character with a legacy. The principal further wonders why no one has raised the mascot issue before, and Chris, now recognized as a Native American who can speak with authority to a white audience, responds, “Maybe they didn't think anyone would listen" (132). Chris has positioned himself as an individual who can speak and be listened to in both communities, which prepares him for his final public pronouncement in the novel.

\section{The surrogate speaks}

The final speech of the novel is shared at the tribal council. Chris shares it physically with his grandfather, who introduces him to the council. In addition, by handing him the letter, Dado publicly acknowledges Chris authority and right to speak to the tribe. His grandfather has led the tribe in the past and is connected to the traditions. This trait is lacking in the current chief as symbolized by his inability to speak his own native tongue fluently.

Occasionally, in older times, the hunter of the tribe would face hardships-and not return. Chris's father is one such hunter, who is lost in a modern day challenge and is not there to lead the people. Chris shares the speech with his father spiritually as he reads the speech his father has prepared. His father writes the letter giving the tribe an alternate piece of land for the casino, and his grandfather announces the intention of the letter in the native tongue. Yet, it is Chris who reads the letter publicly. The gift of the land on the perimeter of the reservation protects the heart of the land. It preserves "a place to come back to" (80). He stands as the surrogate as his family offers up their land for the benefit of the tribe. His family maintains their position as tribal providers and caretakers. He reads his fathers words, "[o]ur family has always defended the heart of our land. We will not stop doing that" (151). The Nicola family, the family of givers, extends an offering of their land, on the fringe of the reservation, for the tribe's use and as a result preserves the island.

Remembering the symbolic possibilities of his names intensifies all three public pronouncements, the impromptu speech on the island, the prepared speech in the classroom, and this final reading of his father's letter at the tribal council. Chris is most powerful as 
the bridge between various groups. He speaks about the divide in the tribe over the casino; he brings a racially diverse group of children together in the white school; he and his grandfather bridge the gap left by his absent father; and Chris begins to speak across communities as represented by his conversations after the class report with the school board member and the principal. He is a giver of gifts; even if it is only the gift of friendship and understanding that he offers. He also functions symbolically as the patron saint of travelers. As the communities and the individuals that comprise them travel into the future, Chris points the way. His speeches in both languages provide a vision that must be considered by members of both the white and native people's communities. In the first and the last instances, he speaks to the issues that confront his tribe internally. In the second instance, he speaks as a representative of his tribe in the larger world. A narrative that places Chris as a spokesman in both worlds suggests that this tribe will need a sagamon

It takes a powerful voice, in a language that both sides understand, to abolish racist stereotypes; yet, a language in and of itself is not enough. capable of making pronouncements in both arenas. This is an ideological vision of the future that has a character, such as Chris, serving as a bridge providing assistance to travelers who are journeying into the future. A future that speaks to the needs of the people who remain on the reservation and to those people who wander outside its perimeter.

\section{Discussing the Smooth Ending and the Ideology}

When the principal, Dr. Moody, points out that there have been eighty years of Chiefs at Rangerville schools "and not one Penacook voice has been raised in complaint until now" (131). Chris answers, "Maybe they didn't think anyone would listen” (132). It takes a powerful voice, in a language that both sides understand, to abolish racist stereotypes; yet, a language in and of itself is not enough. The language and the message must come in a context that all the participants understand and treat as a borderland of negotiation. This paper has argued that the highest praise for a work of adolescent literature is when the literary craft and the ideology are tightly woven into a united presentation. Bruchac displayed a clever and evocative use of language to heighten the novel's literary qualities while still advancing his ideology. The use of names, public discourse, and ultimately the use of symbolic cycles evidence a finely crafted piece of fiction. The ideology of the novel is tied closely to the use of the languages tropes. It is, however, the language that is left unspoken and the narratives left unfinished that reveal the weakness in the novel's ideological presentation.

\section{Ideological Presence}

Much of the ideology of The Heart of a Chief is straightforward. The need for leaders, such as Chris, to emerge among native peoples is evident. The book calls for the active participation of the tribe's newest generation. These young people will be successful if they learn the language and the skills of the white power structure, while still remaining tied to the traditional values of the tribe and the land. It is a difficult task as represented by the failure of Chris's father, Mito. In addition, the older generation of his grandfather can no longer carry the burden. If the author's goal is to provide an optimistic view for the future participation of young native peoples, that goal is achieved. Most young readers of this book will enjoy the book and be satisfied with its seemingly optimistic ending. Nevertheless, the problematic ideological issues, preserving tribal lands, negotiating jobs, and economic security for the future, are left unanswered and weaken the ideological force of the novel. Perhaps a more optimistic interpretation of the ending is to believe that Bruchac has created a character that can bring resolution to these issues in the future.

\section{The Smooth Ending}

While the ending of the novel initially appears to be tidy and might appeal to adolescents and others who long for a nice conclusion, it leaves several ideological issues unsettled. Can the youth of the native peoples in America find a voice among their own people and outside of the tribe as well? If they find the voice, will it be heard? It is difficult to determine if Bruchac thinks finding a voice to speak 
within the boundary of the tribe is more important than speaking in the white world with authority. This is one of the problems of the novel that is left unresolved. While the novel privileges language and its uses in communication, the novel's ending fails to communicate a satisfying conclusion to match the issues it has presented. In which world is Chris really successful? The novel's ending never adequately considers a resolution that addresses the racial conflict that will certainly exist, as the debate over a change in the mascot continues. Chris certainly has allies, Coach Takahashi, his friends, the members of his class group, and perhaps, the star football player. Will their efforts, combined with Chris's actions, be enough to negotiate a change in the eighty-year-old mascot without further conflict? The ending simply leaves the complicated questions of this situation hopeful, but unresolved. It is unrealistic to assume that an ideological issue that is so political charged would be resolved by one classroom debate.

Cultural Decay

The novel's ending never adequately addresses the decay within the reservation that might accompany the construction of a casino on the perimeter of the tribal land. It will bring jobs, but are the Penacook people guaranteed those jobs? A chief who lacks the ability to communicate in the traditional language currently leads them. Furthermore, he has already attempted to make several decisions without the full support of the tribal council, which the novel delineates as a non-native practice. With their gift of land, the Nicola family forces the issue of the casino and its placement on the reservation. A unanimous vote by the council places the Nicola property as the first choice for a casino site. After this vote is taken, the novel abruptly ends. Careful readers realize that no long-term decision has been made, nor have the dangers been outlined and discussed. Whether or not Chris's efforts will support a bridge that is wide enough and firm enough to walk upon in the future is, ultimately, left unanswered by the narrative. Chris's success or failure, combined with the work of the tribal council, has significant ideological importance in the novel's open and questionable ending. Just as the issues surrounding the debate over the mascot are left unresolved, so is the issue of the casino and its influence. What should the tribe do to flourish economically and still protect and nurture their lands and traditions? Perhaps, saving the island from the casino is only the first step in dismissing the casino as an alternative altogether. In reality, the ideological concerns that run throughout the novel are largely left unanswered.

\section{Conclusion}

The Heart of a Chief is an excellent example of a book that exhibits fine examples of literary craftsmanship. The examples of the use of language tropes alone support this claim. This engaging novel has additional merits that further demonstrate its literary qualities. Examples of the development of minor characters, the interweaving of several plots, and juxtaposition of themes and settings could all be discussed to further demonstrate the novels achievements. The ideological arguments of the novel are also clear and represent the issues of reservation life through the emic view of an author who is also Native American. While I enjoyed the novel as a reader, I continue to trouble the novel's ultimate conclusion. I expected the author to demonstrate the resulting difficulties that would flow from the issues. Instead, the ending is too tight, too Disney. This "See, how we can all get along" view one would expect from a writer outside the Native American community with limited, but perhaps well intentioned perspectives. I expected a few more suggestions from a Native American author about how to not only identify these issues, but some plot turn that might suggest how to react to the potential problems. Can I expect every novel to face the reality of every one of its ideological stances? Of course not, the goal as a critic is, as Hollindale suggests, not to advocate for the ideology of any given novel, but to provide the tools for careful 
reading so that all readers can critique those ideologies. The Heart of a Chief is a fine example of a novel that receives high marks in the categories of masterful craftsmanship and of clear ideological statements. It will engage most readers and still leave room for critique and further discussion.

1 All further references and definitions of names are from this website unless otherwise indicated.

\section{Works Cited}

Bruchac, Joseph. The Heart of a Chief: A Novel. 1st ed. New York: Dial Books for Young Readers, 1998.

Campbell, Mike. Behind the Name. September 16, 2003 19962002. Webpage. Mike Campbell. Available: http:// www.behindthename.com/cgi-bin/ search.cgi?terms=christopher. October 10, 2003.

Derrida, Jacques. "Structure, Sign and Play in the Discourse of the Human Sciences." Writing and Difference. Chicago: University of Chicago Press, 1978. xx, 342.
Encarta ${ }^{\circledR}$, Microsoft ${ }^{\circledR}$. Pontiac (Native American Chief). 2003. 1997-2003 Microsoft Corporation 2003. Online Encyclopedia. (c) 1993-2003 Microsoft Corporation. All Rights Reserved. Available: http://encarta.msn.com/encyclopedia_761569237/Pontiac_(Native_American_chief).html. November 16, 2003.

Hollindale, Peter. "Ideology and the Children's Book." Literature for Children: Contempory Criticism. Ed. Peter Hunt. London; New York: Routledge, 1992. 19-40.

Lye, John. Ideology: A Brief Guide. October 18, 1997. internet. Available: http:www.brocku.ca/english/jlye/ideology.html. August 28, 2003.

Woodson, Jacqueline. "Who Can Tell My Story." Whose Story Is It?: Cultural Authenticity within Children's Literature. Eds. D Fox and K Short. Champaign, Illinois: National Council of Teachers of English, 2003.

Yolen, Jane. "Past Time: The Writing of the Picture Book "Encounter."' New Advocate 5.4 (1992): 235-39.

Yolen, Jane, and David Shannon. Encounter. 1st ed. San Diego: Harcourt Brace Jovanovich, 1992.
Joseph Bruchac is a professional teller of the traditional tales of the Adirondacks and of the native peoples of the Northeastern Woodlands. Much of his writing draws on that land and his Abenaki ancestry. He is well known for weaving proverbs and traditional storytelling into the western form of the novel. Steven T. Bickmore spoke with Joseph Bruchac on April 29, 2005, at the Georgia Center, University of Georgia. The following is an excerpt from that interview.

A quote from the interview that might be highlighted is: "The body of work that you have written is like a rough stone from which you carve the final sculpture."

Bickmore: What is the preferred terminology for referring to Native Americans?

Bruchac: The term "American Indian" is used by most American Indians. American Indian is found in the constitution of the United States. Even though it is a misnomer it has been used for over 400 years and because of that most native people in what is now the United States refer to themselves as Indians. We have the National Museum of the American Indian. The two most popular national Indian newspapers are News From Indian Country and Indian Country News. That should be a clue.

The primary point to remember is to refer to people by their own specific tribal nation first, and then if you are talking about native people in general the word Indian or American Indian is perfectly all right.

Bickmore: How people choose to be named seems to become an important issue.

Bruchac: I always say, "Just ask people how do they call themselves." That is the most important 
thing. Unfortunately, most of the people who are studying or writing about American Indians or native people have no contact at all with living native people. They are getting it all out of books, usually secondary books. These books are not what are written by native people, but what is written about Indians by non participant observers.

Bickmore: When writing The Heart of a Chief, how much contemplation did you go through before deciding to use a name like Chris for an Indian boy? It seems highly ironic.

Bruchac: Yes, highly ironic, because you have Christopher Columbus, of course and also you have St. Christopher. You have many names after saints. This is a Catholic Indian community so Saints' names are commonly used. I know native kids named Chris. It is hard to have a discussion in the context of native culture with other native people without having humor and irony.

Bickmore: You often mention the importance of ancestors and passing things on to the next generation. Was there an important connection and influence between you and your immediate ancestors that started you off as a storyteller?

Bruchac: My decision to become a storyteller was forced upon me by my children. Before that I was mostly publishing poetry. Then I had to sort of tell stories for my kids. Because they needed stories and I told traditional stories. That led me to the first book I published for kids which was a collection of some of the stories I told my own children. It is called Turkey Brother, which is a bunch of Iroquois stories.

Bickmore: You write books for both children and young adults. When you are writing up a story when do begin to decide who the audience will be?

Bruchac: Certain things speak their own names to me. A traditional story is a traditional story and it may tell itself in a form, which becomes a children's book or a story that relates to those things that need to be taught to very young people becomes a picture book. The same information might also want itself to be told at greater length. So I have done a picture book called Jim Thorpe's Bright Path. ... I wanted to go forward on that so, I am now working on a young adult novel called Jim Thorpe at Carlyle.

Bickmore: Do you feel that stories have a life of their own and that they find you?

Bruchac: Oh, very definitely. Stories find you. For example, Skeleton Man came to me. It demanded to be told.

Bickmore: What advice do you have for young, aspiring writers?

Bruchac: Don't talk about it. Do it. If you want to be a writer you have to write. The more you write, the better you will get at it. The more you write, the more you will have written. The body of work that you have written is like a rough stone from which you carve the final sculpture. My first drafts are never satisfactory.

Bickmore: Do you see your books as political tools?

Bruchac: Every person dealing with native traditions will say there are at least two purposes to everything you write. One is to entertain. The other is to instruct. Perhaps writing can make it clearer who native people are and what their needs are concerning specific things about particular places and particular times. Parts of history that are maybe misunderstood. These can all be found in many of things that I have written. But I don't set out to write with a political agenda.

Bickmore: Thanks, Joseph.

Bruchac: You are very welcome. 